INTERNATIONAL JOURNAL OF MULTIDISCIPLINARY RESEARCH AND ANALYSis

ISSN(print): 2643-9840, ISSN(online): 2643-9875

Volume 04 Issue 12 December 2021

DOI: 10.47191/ijmra/v4-i12-19, Impact Factor: 6.072

Page No.- 1901-1905

\title{
Dental Health Promotion Using Traditional Media in Elementary School Children: is it Effective?
}

\author{
Wiworo Haryani ${ }^{1}$, Nur Aini Tri Indah Rahmawati ${ }^{2}$, Almujadi ${ }^{3}$ \\ ${ }^{1,2,3}$ Department of Dental Health, Poltekkes Kemenkes Yogyakarta, Yogyakarta, Indonesia
}

\begin{abstract}
The people the behavior of maintaining dental health in elementary school children is still in the low category. This is evidenced by the results of basic health research proving that brushing teeth is good at the age of $5-9$ which is $93.2 \%$ and at the age of $10-14$ it is $96.5 \%$ but only $2.8 \%$ brushes teeth at the right time. Dental health education using traditional media can increase the dental health knowledge of elementary school children. This study aims to analyze the effectiveness of traditional media on increasing dental health knowledge of elementary school children. Methods: This study used a quasi-experimental design with a pretest and posttest with a control group design. The research was conducted at SDN 1 Sumbermulyo and SDN 2 Sumbermulyo, Pasanggaran District, Banyuwangi Regency. The research sample was taken by purposive sampling technique, as many as 48 students consisting of 24 intervention groups and 24 control groups. The intervention group was dental health education using traditional "wayang" media, while the control group was dental health education using power point media. analysis using the paired sample t-test and independent sample t-test. Result: level of knowledge of dental health before and after in the treatment group and control group obtained significancy $p=0.000$ then $p<0.05$ which means dental health education with wayang media and power media point is equally effective in increasing the dental health knowledge of elementary school children. Difference in the level of knowledge between the intervention group and the control group value of $p=0.000$, then $p<0.05$, which means that dental health education using wayang media is more effective in increasing dental and oral health knowledge of elementary school children than using power point media. Conclusion: dental health education using traditional media is effective in increasing the dental health knowledge of elementary school children.
\end{abstract}

KEYWORDS: Dental health education, traditional media, dental health knowledge.

\section{INTRODUCTION}

Dental and oral health cannot be separated from one another, body health because it will affect the overall health of everyone, including children. The condition of the teeth and mouth is said to be healthy if the teeth are yellowish white with intact tooth crowns, the neck of the teeth is not visible, the condition of the gums and oral mucosa is healthy, there are no complaints of pain and halitosis [1-3].

The results of the Basic Health Research show that $57.6 \%$ of the Indonesian population has dental and oral health problems. Based on age group, the percentage of good tooth brushing behavior at the age of 5-9 is $93.2 \%$ and at the age of $10-14$ is $96.5 \%$ but only $2.8 \%$ brushes their teeth at the right time, which is at least twice, after breakfast and before bed. One of the factors that cause dental and oral health problems is behavioral factors. Behavior that tends to ignore dental and oral hygiene is generally based on a lack of knowledge about dental and oral health and its maintenance $[4,5]$.

Age 7-12 years is an important age in the growth and development of children. This period can be called a critical period because children begin to develop habits and behavioral. Children can be categorized as a group that is prone to dental and oral problems, especially cavities. This is due to the nature and attitude of children who do not know about the importance of maintaining the condition of the teeth. Efforts to maintain dental and oral health especially in elementary school children need special attention because at that age children are undergoing a process of growth and development. The condition of the previous teeth will affect the development of dental health in later adulthood $[6,7]$.

Behavioral factors based on a lack of knowledge about dental and oral health maintenance will increase the incidence of dental and oral diseases at an early age. Cognitive knowledge is an important factor for the formation of one's actions where knowledge based on the right understanding will lead to the expected new behavior. Health education is part of health 


\section{Dental Health Promotion Using Traditional Media in Elementary School Children: is it Effective?}

promotion to influence a person to behave well in maintaining dental and oral health, increase public awareness of dental and oral health, provide understanding of ways to maintain dental and oral health, and prevent disease to improve oral health and child welfare. Health education will be more effective and the results will be optimal when using appropriate health education methods and media, including using traditional media and methods [8-10].

The traditional media "Wayang" is a cultural heritage that is rich in stories and meanings. Wayang is not only functioned as a means of entertainment by the people of Indonesia, but wayang has also become a medium of information and communication to convey a message or teaching, such as the spread of religion, counseling and education. Until now, the art of wayang performance is still very popular with people on the island of Java, especially in Mulyo Asri Hamlet, Sumbermulyo Village, Pesanggaran District, Banyuwangi Regency, East Java. This is evidenced by the constant holding of wayang performances to commemorate certain days such as independence day, celebrations, and sea picking which are usually held at the Village Hall or Field [11,12].

The selection of wayang as a medium to be used in dental health education activities is based on the fact that puppet shows are still active and the local community often uses regional languages in daily conversation, so it is hoped that the extension materials will be easily accepted and understood by the counseling participants. Several studies have proven that the use of wayang character media is effective in increasing student interest and learning outcomes. Research Utami which also shows that there is an increase in knowledge before and after counseling in the wayang and booklet groups [13,14].

\section{METHOD AND MATERIAL}

The method used in this research is a quasi experiment with a pre and post-test design with a control group design. The research was conducted at SDN 1 Sumbermulyo and SDN 2 Sumbermulyo, Pasanggaran District, Banyuwangi Regency in January-March 2021. The research sample was taken by purposive sampling technique, as many as 48 students consisting of 24 intervention groups and 24 control groups. The intervention group was dental health education using traditional "wayang" media, while the control group was dental health education using power point media.

The instrument for collecting data on dental health knowledge was measured using a questionnaire that had been tested for validity and reliability by previous research Pratiwi [15]. The research stages include preparing "wayang" media as many as 4 characters made by artists. The wayang characters created are in the form of cartoon characters who have roles as children, mothers, village heads, and dentists and at the stage of carrying out pre-test activities with questionnaires, then dental health education interventions are carried out according to groups and finally post-tests are carried out by giving questionnaires.

Analysis of the data used is the normality test using the Kolmogorov Smirnov test. This test aims to determine whether the data is normally distributed or not. The data in this study were normally distributed, so they were analysis using the paired sample ttest and independent sample t-test.

\section{RESULT}

Table 1. Frequency distribution of respondent characteristics

\begin{tabular}{lllllll}
\hline \multirow{2}{*}{$\begin{array}{l}\text { Respondent } \\
\text { characteristics }\end{array}$} & \multicolumn{2}{l}{ Intervention group } & \multicolumn{2}{c}{ Control group } & \multicolumn{2}{c}{ Total } \\
\cline { 2 - 7 } & $\mathrm{n}$ & $\%$ & $\mathrm{n}$ & $\%$ & $\mathrm{n}$ & $\%$ \\
\hline Gender & 8 & 33.3 & 17 & 70.8 & 25 & 52.0 \\
Male & 16 & 66.6 & 7 & 29.1 & 23 & 48.0 \\
Female & 24 & 100 & 24 & 100 & 48 & 100 \\
\hline Total & 5 & & & & & \\
\hline Age & 19 & 79.1 & 15 & 62.5 & 34 & 70.9 \\
10 year & 24 & 100 & 24 & 100 & 48 & 100 \\
11 year & & & & & & \\
\hline Total & & & & & & \\
\hline
\end{tabular}

Table 1 shows that the largest number of respondents were male, namely 25 people (52.0\%) and the highest number of respondents came from the 11 year age group, namely 34 people (70.9\%). 
Dental Health Promotion Using Traditional Media in Elementary School Children: is it Effective?

Table 2. Frequency distribution of dental health knowledge in the intervention group and control group

\begin{tabular}{lllllllll}
\hline \multirow{2}{*}{ Knowledge } & \multicolumn{3}{l}{ Intervention group } & \multicolumn{3}{l}{ Control group } \\
\cline { 2 - 10 } & \multicolumn{2}{l}{ Pretest } & \multicolumn{2}{l}{ Posttest } & \multicolumn{2}{l}{ Pretest } & \multicolumn{2}{l}{ Posttest } \\
\cline { 2 - 10 } & $\mathrm{n}$ & $\%$ & $\mathrm{n}$ & $\%$ & $\mathrm{n}$ & $\%$ & $\mathrm{n}$ & $\%$ \\
\hline Good & 10 & 41.7 & 24 & 100 & 17 & 70.8 & 21 & 87.5 \\
Enough & 14 & 58.3 & 0 & 0 & 7 & 29.1 & 3 & 12.5 \\
Bad & 0 & 0 & 0 & 0 & 0 & 0 & 0 & 0 \\
\hline Total & 24 & 100 & 24 & 100 & 24 & 100 & 24 & 100 \\
\hline
\end{tabular}

Table 3 shows that the most respondents who have knowledge in the good category after being given dental health education are the intervention group, namely 24 people (100\%) and the control group 21 people ( $87.5 \%)$.

Table 3. Normality and homogeneity test results

\begin{tabular}{lll}
\hline Group & $\mathrm{n}$ & $\mathrm{p}$-value \\
\hline Normality test & & \\
\hline Intervention (Pre-test) & 24 & 0.929 \\
Intervention (Post-test) & 24 & 0.317 \\
Control (Pre-test) & 24 & 0.653 \\
Control (Post-test) & 24 & 0.160 \\
\hline Homogeneity test & & \\
\hline Intervention (Pre-test) & 24 & 0.180 \\
Intervention (Post-test) & 24 & 0.787 \\
Control (Pre-test) & 24 & 0.260 \\
Control (Post-test) & 24 & 0.113 \\
\hline
\end{tabular}

The normality test of the data has been carried out using the Kolmogorov Smirnov-Test with the provision that if the $p$ value $>$ 0.05 then the data is normally distributed, whereas if the $p$ value $<0.05$ then the data is not normally distributed. The data in table 4 shows that the four data have a $\mathrm{p}$ value $>0.05$ which means the data is normally distributed.

Homogeneity test was conducted to determine the homogeneity of the data. The significant value obtained from all data is > 0.05 so it can be concluded that the variance of the two data groups is the same (homogeneous).

Table 4. Test the effectiveness of dental health knowledge before and after education in the intervention and control groups

\begin{tabular}{lll}
\hline Knowledge & $\mathrm{p}$-value & explication \\
\hline Intervention group & 0.000 & Significant \\
Control group & 0.000 & Significant \\
\hline
\end{tabular}

*Paired Sample T-Test

Table 4 shows that the results of the analysis using a paired sample t-test for the level of knowledge of dental health before and after in the treatment group and control group obtained significancy $p=0.000$ then $p<0.05$ which means dental health education with wayang media and power media point is equally effective in increasing the dental health knowledge of elementary school children

Table 5. Different test of dental health knowledge in the intervention and control groups

\begin{tabular}{lll}
\hline Knowledge & $p$-value & explication \\
\hline Intervention group & 0.000 & Significant \\
Control group & & \\
\hline
\end{tabular}

*Independent Sample T-Test 


\section{Dental Health Promotion Using Traditional Media in Elementary School Children: is it Effective?}

The results of different tests using the Independent Sample t-test were used to determine whether or not there was a difference in the level of knowledge between the intervention group and the control group. Based on table 5 , it was obtained that the significance value of $p=0.000$, then $p<0.05$, which means that dental health education using wayang media is more effective in increasing dental and oral health knowledge of elementary school children than using power point media.

\section{DISCUSION}

The results showed the frequency distribution of male respondents as many as 25 people (52.0\%) while female respondents 23 people (48.0\%) and respondents in the 10 year age group as many as 14 people (29.1\%) while the age 11 years 34 people (70.9\%).

The level of knowledge with both categories before and after using the wayang media on the respondents showed that there was an increase from 10 people (41.7\%) to 24 people (100\%). Respondents who were given counseling using power point media also increased from 17 people (70.8\%) to 21 people (87.5). The data shows that there are differences in the level of knowledge before and after health counseling in each group as evidenced by the increasing number of respondents with good knowledge, which means that dental and oral health counseling can increase a person's knowledge from not knowing to knowing.

The most significant increase occurred in the intervention group who were given education using wayang media. According to the researcher, this is because wayang media has a concept of human character which is developed into several characters such as the character of children, mothers, fathers, village heads and dentists to support the stories conveyed so that it is more interesting for students to listen to the information conveyed. This is in line with Levie \& Lentz in Fendrik who also suggested that visual symbols or images facilitate children to understand, remember messages contained in images, and clarify information, and puppet media is one of the media that is categorized as a type of visual media [16].

The results of the respondent's Paired Sample T-test showed differences in the level of knowledge before and after dental health education was carried out. The results of the pretest and posttest showed that dental and oral health promotion activities could increase children's knowledge about dental and oral health. According to the researcher, the change in the respondent's level of knowledge was caused by the use of media as a means of counseling, this was reinforced by the WHO statement that the use of educational methods or media greatly determines the success of delivering health education. Haris et al. says that the media functions to direct the senses as much as possible to an object so as to facilitate perception, in other words the media makes it easier for someone to understand material that is considered complicated. The results of this study are in line with research conducted by Kantohe et al. that respondents experienced an increase in dental and oral health knowledge after being given an intervention in the form of counseling using the media $[17,18]$.

The results of different tests using the Independent Sample t-test were used to determine whether or not there was a difference in the level of knowledge between the intervention group and the control group. Based on table 5 , it was obtained that the significance value of $p=0.000$, then $p<0.05$. This shows that health promotion using wayang media is more influential in increasing students' knowledge than power point media. This can happen because the wayang media used in this study are models of human characters such as mothers, children, dentists, and village heads which are adapted to the characters in the story and are given a bamboo stick or handle to move it so that it attracts respondents' interest in listening to the story that will be told. impact on student learning outcomes in the extension activities carried out. In addition, the advantages of wayang media are: efficient, increase students' enthusiasm and enthusiasm in participating in the learning process so that students are encouraged to actively participate in outreach activities which are expected to have an impact on increasing information acceptance results. Strengthen the statement regarding the function of wayang media by saying that wayang media is also able to improve children's skills in listening to stories, developing imagination and creating a happy atmosphere. The results of this study are in line with research conducted by Buana that the use of wayang figures media is effective in increasing student interest and learning outcomes $[13,19]$.

\section{CONCLUSIONS}

Based on the results of the study, it can be concluded that dental health education using traditional media is effective in increasing the dental health knowledge of elementary school children.

\section{ACKNOWLEDGMENT}

This study was done by self- funding from the authors. The authors thank to all partisipants and research assistan.

\section{REFERENCES}

1) Pudentiana RR, Purnama T, Tauchid SN, Prihatiningsih N. Knowledge of Oral and Dental Health Impacts the Oral 


\section{Dental Health Promotion Using Traditional Media in Elementary School Children: is it Effective?}

Hygiene Index Simplified (OHI-S) of Primary School Children. Indian J Forensic Med Toxicol 2021;15:2179-83.

2) Kasihani NN, Ngatemi TP, Purnama T. Determinants of Parental Behavior in Maintaining Deciduous Teeth in Early Childhood: A Cross Sectional Study. Eur J Mol Clin Med n.d.;8:2021.

3) Rickne CS, Weiss G. Woelfel's Dental Anatomy 2016.

4) Kementerian Kesehatan RI. Hasil utama riskesdas 2018. Jakarta Kemenkes RI 2018.

5) Yulita I, Purnama T, Marliani Y. Knowledge and Attitudes of Dental and Oral Health Maintenance in Pregnant Women (Case Study: Obstetrics and Gynecology Polyclinic at Pertamina Central Hospital, Jakarta). Int Res J Pharm Med Sci 2021;4:9-11.

6) Wawointana IP, Umboh A, Gunawan PN. Hubungan konsumsi jajanan dan status karies gigi siswa di SMP NEGERI 1 Tareran. E-GiGi 2016;4.

7) Prasko P, Santoso B, Sutomo B. Penyuluhan metode audio visual dan demonstrasi terhadap pengetahuan menyikat gigi pada anak sekolah dasar. J Kesehatan Gigi 2016;3:53-7.

8) Ngatemi, Purnama T. Dental Health Handbook as Parents Monitoring in the Formation of Independence for Brushing Teeth in Early Childhood. Indian J Public Heal Res Dev 2020;11.

9) Notoatmodjo S. Ilmu perilaku kesehatan. Jakarta: Rineka Cipta 2010;200:26-35.

10) Andriany $P$, Novita CF, Aqmaliya S. Perbandingan efektifitas media penyuluhan poster dan kartun animasi terhadap pengetahuankesehatan gigi dan mulut (Studi pada Siswa/i Kelas V SDN 24 Kota Banda Aceh). J Syiah Kuala Dent Soc 2016;1:65-72.

11) Lestari W, Wulansari S. Pertunjukan Wayang Interaktif Sebagai Sarana Promosi Kesehatan Remaja Tentang Rokok, Narkoba Dan Pergaulan Bebas. Bul Penelit Sist Kesehat 2018;21:125-32.

12) Nurgiyantoro B. Wayang dan pengembangan karakter bangsa. J Pendidik Karakter 2011;1.

13) Buana AP. Keefektifan Media Wayang Tokoh Dalam Pembelajaran Cerita Pendek Ditinjau Dari Minat Dan Hasil Belajar Siswa Kelas V SD Negeri Harjosari Lor 2 Kabupaten Tegal 2019.

14) Utami MA. Pengaruh Media Wayang dan Booklet Terhadap Pengetahuan Gizi Seimbang Anak Sekolah Dasar. Indones J Heal Dev 2020;2:154-62.

15) Pratiwi Y. Efektivitas Penyuluhan Kesehatan Gigi Menggunakan Media Wayang dan Boneka Tangan Terhadap Keterampilan Menyikat Gigi Sdn Mekarsari Kabupaten Musi Rawas Sumatera Selatan 2020.

16) Fendrik M. The Effect of Media Visual in Three Dimensions Towards the Result of Math Learning at Elementary School. Pendas J IIm Pendidik Dasar 2017;2:1-14.

17) Haris VSD. Pengaruh Penyuluhan Dengan Media Animasi Terhadap Pengetahuan Dan Sikap Tentang Makanan Bergizi, Seimbang Dan Aman Bagi Siswa SD 08 Cilandak Barat Jakarta Selatan Tahun 2017. Qual J Kesehatan 2018;12:38-42.

18) Kantohe ZR, Wowor VNS, Gunawan PN. Perbandingan efektivitas pendidikan kesehatan gigi menggunakan media video dan flip chart terhadap peningkatan pengetahuan kesehatan gigi dan mulut anak. E-GiGi 2016;4.

19) Sumaryanti E, Sabri T, Rosnita R. Penggunaan Media Wayang Pada Pembelajaran Tematik Untuk Meningkatkan Hasil Belajar Di Sekolah Dasar. J Pendidik Dan Pembelajaran Khatulistiwa 2018;7. 